\title{
The Effect of Fundamental and Macroeconomic Factors on Agricultural Sector Company Stock Prices Listed in the Indonesia Stock Exchange on the 2016- 2018 Period
}

\author{
Mayasir Aziza*, Suryadi, Atika Syuliswati \\ Accounting Department \\ State Polytechnic of Malang \\ Malang, Indonesia \\ *mayasiraziza19@gmail.com
}

\begin{abstract}
The aim of this research is to investigate influence of Fundamental and Macroeconomic Factors for Stock Prices partially and simultaneously testing on the Indonesia Stock Exchange agriculture sector in the 2016-2018 based on Earning per Share (EPS), Return On Assets (ROA), Dividend Per Share (DPS), Debt to Equity Ratio (DER), Dividend Yield, Oil Prices, and exchange Rate. The sample consisted of 12 agriculture companies. This research used multiple regression analysis. The result of the Research indicated that EPS, DPS, DER, partially has a significant effect on stock prices. and simultaneously the research variable has a significant effect on stock prices. the results of this research expected to help Investor to make investment decisions.
\end{abstract}

Keywords-Earning Per Share (EPS) Return On Assets (ROA), Dividend Per Share (DPS), Debt to Equity Ratio (DER), dividend yield, oil prices, exchange rate

\section{INTRODUCTION}

Indonesia is a country that has abundant natural resources consisting of water, land, forests, sea and biodiversity on every island in Indonesia and supports the development of various sectors [1]. Indonesia has a potential area for agriculture with 70.59 million hectares of dry land, 5.23 million hectares of non-swampy wetlands, and 19.99 million hectares of swampland, but it has not been optimally utilized [2].

One of the goals of investors in investing in stocks is to maximize wealth from capital gains or profits from the difference in the purchase and sale price of shares so that factors that affect stock prices are important information for investors [3]. Fundamental information is often used by investors to predict stock prices [4]. One of the analytical tools used to assess the company's stock price is to use fundamental analysis or financial ratio analysis [5].

Macroeconomic changes in Indonesia will affect the Indonesian economy and the whole industry that is on the Indonesian stock exchange [6]. Macroeconomics is an environment that exists outside the company and affects company performance and share prices because the impact cannot be avoided which is aimed at all companies on the IDX [7].

\section{Methods}

The population in this study were all companies on the main board and development boards listed in the BEI agricultural sector for the 2016-2018 period. The research sample was taken based on purposive sampling technique, namely determining the sample based on certain considerations. In this study, the research samples were 12 companies in the agricultural sector. The variables in this study consist of EPS, ROA, DPS, DER, Dividend Yield, Oil Price, and Exchange Rate as the independent variable and stock price as the dependent variable.

Data collection methods use documentation to obtain data on stock prices, EPS, ROA, DPS, DER, dividend yield, oil prices, and exchange rates.

\section{RESULTS AND DISCUSSION}

Based on the results of descriptive statistical tests by comparing the mean and standard deviation, it is known that the company's stock price is homogeneous or between one company and another is the same, the company's EPS is heterogeneous or between one company and another company is different, the company's ROA is heterogeneous, Company DPS is heterogeneous, company DER is heterogeneous, dividend yield is heterogeneous, company oil price is homogeneous, firm exchange rate is homogeneous. 


\section{A. Normality test}

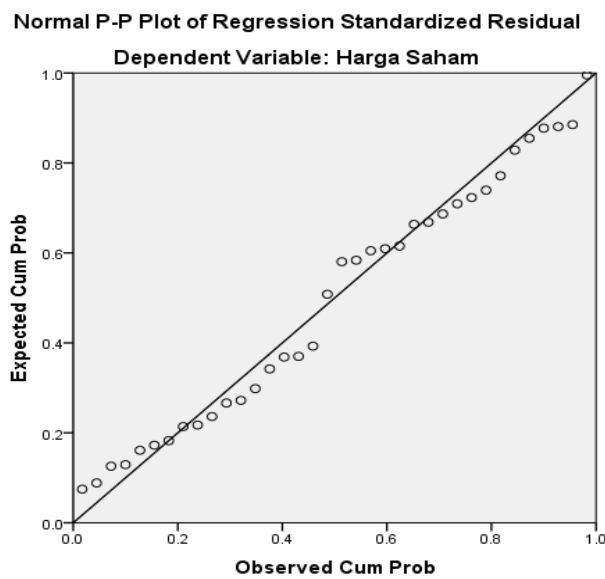

Based on the normal P-P Plot of Regression Standardized Residual graph above, it can be seen that the dots spread around the diagonal line and the distribution follows the direction of the diagonal line. so that in this case it shows that the regression model is feasible because it has met the assumption of normality.

TABLE I. KOLMOGOROV-SMIRNOV

\begin{tabular}{|c|c|c|}
\hline & & $\begin{array}{c}\text { Unstandardized } \\
\text { Residual }\end{array}$ \\
\hline & N & 36 \\
\hline Normal & Mean & .0000000 \\
\hline Parameters ${ }^{\mathrm{a}, \mathrm{b}}$ & Std. Deviation & 436.72755664 \\
\hline Most Extreme & Absolute & .092 \\
\hline Differences & Positive & .092 \\
\hline & Negative & -.090 \\
\hline Test Statistic & & .092 \\
\hline Asymp. Sig. (2-tai & & $.200^{\mathrm{c}, \mathrm{d}}$ \\
\hline
\end{tabular}

In this study, the Kolmogorov-Smirnov test shows that the significance value is $0.200(0.200>0.05)$ so it can be concluded that the data in this study are normally distributed and the data is suitable for use in research.

\section{B. Classic Assumption Test}

\section{1) Multicollinearity test}

TABLE II. VIF TEST

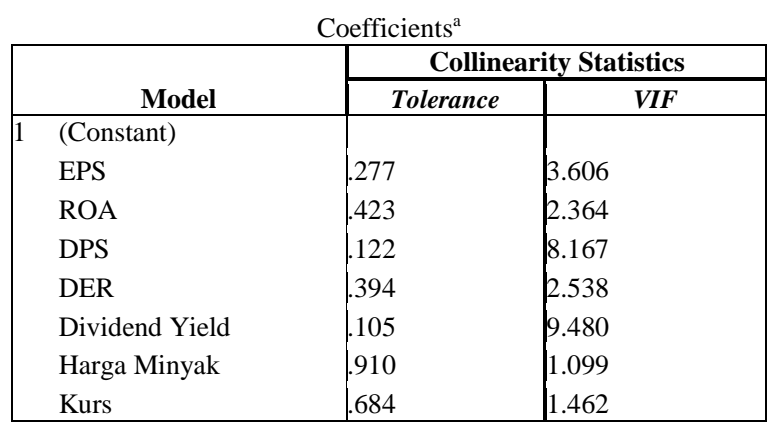

Based on the table above, it can be seen that all independent variables have a VIF value of $<10$, so that in the multicollinearity test there is no very strong correlation between the independent variables so that it does not show symptoms of multicollinearity.

\section{2) Heteroscedasticity test}

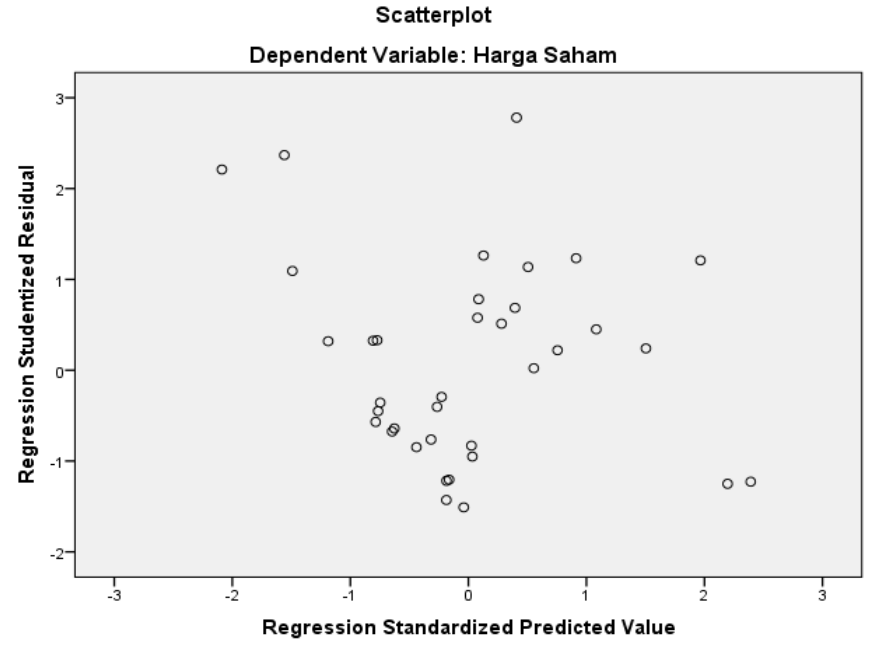

Based on the results of the scatterplot test above, it can be seen that the dots spread above and below or around the number 0 , where the data points also do not collect only above or below, and the data points do not form a wavy pattern that widens then narrows and widen again or the dots don't form a pattern. So it can be concluded that heteroscedasticity does not occur.

\section{3) Autocorrelation test}

TABLE III. AUTOCORRELATION TEST

\begin{tabular}{|l|l|}
\hline & \multicolumn{1}{|c|}{ Unstandardized Residual } \\
\hline Test Value ${ }^{\mathrm{a}}$ & 54.56160 \\
Cases $<$ Test Value & 18 \\
Cases >= Test Value & 18 \\
Total Cases & 36 \\
Number of Runs & 17 \\
$Z$ & .507 \\
Asymp. Sig. (2-tailed) & .612 \\
\hline
\end{tabular}

Based on the table above, it can be seen that in the Runs test, the significance value is 0.612 , which means it is greater than 0.05 , so it shows that there is no autocorrelation. 


\section{Multiple Regression Analysis}

TABLE IV. Multiple REgRession ANALysis Coefficients $^{\mathrm{a}}$

\begin{tabular}{|c|c|c|c|c|c|}
\hline \multirow[b]{2}{*}{ Model } & \multicolumn{2}{|c|}{$\begin{array}{c}\text { Unstandardized } \\
\text { Coefficients }\end{array}$} & \multirow{2}{*}{\begin{tabular}{|c}
$\begin{array}{c}\text { Standardized } \\
\text { Coefficients }\end{array}$ \\
Beta \\
\end{tabular}} & \multirow[t]{2}{*}{$\mathbf{T}$} & \multirow[t]{2}{*}{ Sig. } \\
\hline & $\boldsymbol{B}$ & Std. Error & & & \\
\hline (Constant) & -368.953 & 3162.006 & & -.117 & .908 \\
\hline EPS & 3.279 & .946 & .694 & 3.465 & .002 \\
\hline ROA & -2.235 & 13.463 & -027 & -.166 & .869 \\
\hline DPS & 25.662 & 9.261 & .835 & 2.771 & .010 \\
\hline DER & -111.433 & 40.967 & -.457 & -2.720 & .011 \\
\hline $\begin{array}{l}\text { Dividend } \\
\text { Yield }\end{array}$ & -222.574 & 178.976 & -.404 & -1.244 & .224 \\
\hline $\begin{array}{l}\text { Harga } \\
\text { Minyak }\end{array}$ & -32.393 & 21.097 & -.170 & -1.535 & .136 \\
\hline Kurs & .212 & .209 & .129 & 1.014 & .319 \\
\hline
\end{tabular}

Based on the table above, column B with the first row showing the constant (a) and the next row showing the independent variable (b), the equation is as follows:

$\mathrm{Y}=-\mathbf{3 6 8 , 9 5 3}+3,279$ EPS - 2,235 ROA + 25,662 DPS 111,433 DER - 222,574 Dividend Yield - 32,393 Oil Price + 0,212 Exchange Rate

D. Coefficient of Determination (R2)

TABLE IV. COEFFICIENT OF DETERMINATION

\begin{tabular}{|l|c|c|l|c|c|}
\hline \multicolumn{7}{|c|}{ Model Summary $^{\mathrm{b}}$} \\
Model & $\mathbf{R}$ & $\begin{array}{c}\text { R } \\
\text { Square }\end{array}$ & $\begin{array}{c}\text { Adjusted } \\
\text { R Square }\end{array}$ & $\begin{array}{c}\text { Std. Error of the } \\
\text { Estimate }\end{array}$ & Durbin-Watson \\
\hline 1 & $.830^{\mathrm{a}}$ & .689 & .611 & 488.276 & 1.718 \\
\hline
\end{tabular}

In this study it is known that the level of significance is $5 \%$ with degrees of freedom df $1=7$ and df $2=29$, then the Ftable value is 2.35 and the Fcount value is 8.842 so that the comparison is $8.842>2.35$ or Fcount> Ftable which means that Ha accepted and Ho was rejected. Judging by the calculated significance of 0.000 , which means $<0.05$, this shows that simultaneously there is a significant influence on the variables EPS, ROA, DPS, DER, dividend yield, oil price, and exchange rate on the company's stock price in the agricultural sector listed in IDX 2016-2018 period.

\section{E. F Test}

TABLE V. TEST RESULTS F

\begin{tabular}{|c|c|c|c|c|c|c|}
\hline \multicolumn{7}{|c|}{ ANOVA $^{\mathrm{a}}$} \\
\hline & Model & $\begin{array}{c}\text { Sum of } \\
\text { Squares }\end{array}$ & Df & $\begin{array}{c}\text { Mean } \\
\text { Square }\end{array}$ & $\mathbf{F}$ & Sig. \\
\hline 1 & $\begin{array}{l}\text { Regressio } \\
\mathrm{n}\end{array}$ & 14756038.083 & & $\begin{array}{l}2108005.4 \\
40\end{array}$ & 8.842 & $.000^{\mathrm{b}}$ \\
\hline & Residual & 6675583.555 & 28 & $\begin{array}{l}238413.69 \\
8\end{array}$ & & \\
\hline & Total & 21431621.639 & 35 & & & \\
\hline
\end{tabular}

In this study it is known that the level of significance is $5 \%$ with degrees of freedom df $1=7$ and df $2=29$, then the Ftable value is 2.35 and the Fcount value is 8.842 so that the comparison is $8.842>2.35$ or Fcount> Ftable which means that Ha accepted and Ho was rejected. Judging by the calculated significance of 0.000 , which means $<0.05$, this shows that simultaneously there is a significant influence on the variables EPS, ROA, DPS, DER, dividend yield, oil price, and exchange rate on the company's stock price in the agricultural sector listed in IDX 2016-2018 period.

\section{F. T Test}

TABLE VI. TEST RESULTS T

\begin{tabular}{|l|l|l|}
\multicolumn{3}{c|}{ Coefficients $^{\mathrm{a}}$} \\
\hline \multicolumn{1}{|c|}{ Model } & \multicolumn{1}{c|}{ T } & \multicolumn{1}{c|}{ Sig. } \\
\hline (Constant) & -.117 & .908 \\
EPS & 3.465 & .002 \\
ROA & -.166 & .869 \\
DPS & 2.771 & .010 \\
DER & -2.720 & .011 \\
Dividend Yield & -1.244 & .224 \\
Harga Minyak & -1.535 & .136 \\
Kurs & 1.014 & .319 \\
\hline
\end{tabular}

The t-count value is 3,465 which means that the significance is $<0.05$. Thus it can be concluded that the EPS variable has a significant positive effect on the stock price of the sample companies.

ROA variable has no effect on stock prices. DPS variable has a significant positive effect on stock prices. DER variable has a significant effect on the company's stock price. dividend yield variable has no effect on stock prices. oil price variable has no effect on stock prices. exchange rate variable has no effect on the company's stock price.

\section{CONCLUSION}

The research objective is to examine the effect of independent variables consisting of EPS, ROA, DPS, DER, dividend yield, oil price and exchange rate on the dependent variable stock prices in the 2016-2018 period partially and simultaneously.

Based on the partial test, the research results show that partially Earning Per Share (EPS) has a significant positive effect on stock prices because EPS can affect stock returns and is an important factor in consideration for investors, Partially Return On Assets (ROA) has no effect on stock prices because there are other variables that are considered by investors in making stock investment decisions. partially dividend per share (DPS) has a significant effect on stock prices because investors are interested in company dividends, Debt to equity ratio (DER) has a significant effect on stock prices because DER can affect stock returns, dividend yield has no effect on stock prices because more many companies in the agricultural sector did not 
pay dividends during the study period, oil prices have no effect on stock prices because oil prices have a small and varied impact on agricultural sector performance, exchange rates have no effect on stock prices because companies in the agricultural sector in the study period have not can provide high stock returns to investors from both dividends and capital gains.

And based on the research results simultaneously show that the variables EPS, ROA, DPS, DER, dividend yield, oil price, and exchange rate simultaneously have a significant effect.

\section{REFERENCES}

[1] R. Widyawati, "Analisis Keterkaitan Sektor Pertanian dan Pengaruhnya terhadap Perekonomian Indonesia”. Jurnal Economia, 13(1), 14-27. 2017.
[2] F.R. Zamzany, E. Setiawan, and E.N. Azizah, "Reaksi Sinyal Keuangan terhadap Harga Saham Sektor Pertanian di Indonesia”. Jurnal Bisnis dan Manajemen, 8(2), 133-140. 2018.

[3] I. Wahyuni and S. Djamaluddin, "Pengaruh Kinerja Keuangan terhadap Capital Gain pada Industri Properti di Bursa Efek Indonesia”. Jurnal Ilmiah Manajemen dan Bisnis, 2(1), 111-128. 2016.

[4] T. Samsuar and Akramunnas, "Pengaruh Faktor Fundamental dan Teknikal terhadap Harga Saham Industri Perhotelan yang terdaftar di Bursa Efek indonesia”. Jurnal Masharafiyah, 1(1), 116-131. 2017.

[5] Efrizon, "Pengaruh Rasio Keuangan terhadap Harga Saham Perusahaan Otomotif Periode 2013-2017’. Jurnal Akuntansi Aktual, 6(1), 250-260. 2019.

[6] R. Astuti, J. Lapian, and P.V. Rate, "Pengaruh Faktor Makro Ekonomi terhadap Indeks Harga Saham Gabungan (ISHG) di Bursa Efek Indonesia (BEI) Periode 2006-2015". Jurnal Berkala Ilmiah Efisiensi, 16(2), 399-406. 2016.

[7] I.P.W.P. Asmara and A.A.G Suarjaya, "Pengaruh Variabel Makro Ekonomi terhadap Indeks Harga Saham Gabungan". E-Jurnal Manajemen Unud, 7(3), 1397-1425. 2018. 